\title{
Seminal Attributes and Semen Cryo-banking of Nepalese Indigenous Achhami (Bos indicus) Bull under Ex-situ Conservation
}

\author{
Pankaj Kumar Jha ${ }^{1, *}$, Saroj Sapkota ${ }^{1}$, Neena Amatya Gorkhali ${ }^{1}$, Bhoj Raj Pokharel ${ }^{1}$, \\ Ajeet Kumar Jha ${ }^{2}$, Shishir Bhandari ${ }^{1}$ and Bhola Shankar Shrestha ${ }^{3}$ \\ ${ }^{1}$ Animal Breeding Division, Nepal Agricultural Research Council (NARC), Kathmandu 1950, Nepal \\ ${ }^{2}$ Department of Veterinary Gynaecology and Obstetrics, West Bengal University of Animal and Fisheries Sciences, \\ Kolkata 037, India \\ ${ }^{3}$ Heifer International, Hattiban, Lalitpur 6043, Nepal
}

Received September 26, 2019

Revised December 10, 2019

Accepted December 26, 2019

\section{*Correspondence}

Pankaj Kumar Jha

E-mail: drpankaj.np@gmail.com

ORCID

https://orcid.org/0000-0001-6374-9201
ABSTRACT The study was conducted to evaluate the seminal attributes and cryobanking of Achhami (Bos indicus) bull semen. Of two Achhami bulls, 8 ejaculates from each bull were evaluated for seminal attributes. For semen freezing and cryo-banking, 4 ejaculates (having $\geq 2 \mathrm{~mL}$ semen volume, $\geq 75 \%$ of sperm motility and $\geq 1,000 \times 10^{6}$ cells $/ \mathrm{mL}$ of sperm concentration) from each bull were used. Semen samples were diluted in egg-yolk-tris-citrate extender using a two-step dilution protocol, and were frozen in liquid nitrogen $\left(\mathrm{LN}_{2}\right)$ vapour in a styrofoam box. The mean semen volume, colour, sperm mass activity, motility, viability, concentration, abnormal acrosome, midpiece and tail and, abnormal head of two Achhami bulls were $4.4 \pm 0.5 \mathrm{~mL}$ vs. $2.5 \pm 0.2 \mathrm{~mL}, 2.5 \pm 0.1$ vs. $2.4 \pm 0.1,3.5 \pm 0.1$ vs. $3.5 \pm 0.1,77.0 \pm 1.1 \%$ vs. 78.3 $\pm 1.3 \%, 94.4 \pm 0.5 \%$ vs. $91.0 \pm 0.6 \%, 1137.7 \pm 73.7 \times 10^{6}$ cells $/ \mathrm{mL}$ vs. $1060.0 \pm$ $44.3 \times 10^{6} \mathrm{cells} / \mathrm{mL}, 10.2 \pm 0.5 \%$ vs. $10.3 \pm 0.5 \%$ and $6.7 \pm 0.5 \%$ vs. $8.2 \pm 0.3 \%$, respectively. The post-thawed sperm motility and viability were $53.0 \pm 2.0 \%$ vs. $50.0 \pm$ $0.0 \%$ and $80.2 \pm 0.4 \%$ vs. $73.2 \pm 0.7 \%$, while evaluating by computer-assisted sperm analysis (CASA) system, the percentage of the progressive motility, fast motility, slow motility, local motility and immotile sperm were $75 \%, 68 \%, 7.4 \%, 16.6 \%$ and $8.6 \%$, respectively. A total number of 620 doses semen straw were cryo-banked. Due to the acceptable post-thawed sperm motility and viability recorded, cryopreservation of Achhami semen is hereby recommended so as to preserve the Achhami breed. For further validation, the fertility will be observed from the produced frozen semen.

Keywords: Achhami bull, Nepal, semen cryopreservation

\section{INTRODUCTION}

Acchami (Bos indicus), an indigenous cattle breed of $\mathrm{Ne}^{-}$ pal- perhaps the smallest cattle breed in the world. They are found in western parts of hills- Achham, Bajhang,
Bajura and Doti district of Nepal (700-1,500 msl; Shrestha and Shrestha, 1998). The peculiarities of this breed are their small size, less than 1 meter in height at the withers. This breed is also called Sano Gai or Naumuthe Gai (measures only nine fists from its hoof to hump, Wagle, 2019) 
This breed measures $149.38 \pm 5.1 \mathrm{~kg}$ (adult body weight), $90.8 \pm 0.96 \mathrm{~cm}$ (height at wither) and $98.07 \pm 1.52 \mathrm{~cm}$ (body length; Neopane and Pokharel (2005)). Introduction of exotic breeds, indiscriminate cross breeding, illegal trading to Tibet for slaughtering, and neglect from local people due to less economic returns (milk production capacity $1.5 \pm 0.22 \mathrm{~L}$; Wagle, 2019) results in genetic dilution and decreasing in population. The breed is in endanger state as the number of this breed has reached below 1,000 throughout Nepal (Wagle, 2019). Indigenous animals are the valuable genetic property of a country. The unique characteristics of this breed need to be conserved. A very simple technology is to conserve the genetics materials and disseminate in future is the cryopreservation of semen. However, this technology needs preliminary study of seminal characteristics. Seminal attributes is the basic step towards semen cryopreservation to ensure both the freezing and fertilizing capability (Verstegen et al., 2002; Dhurvey et al., 2012). In Nepal, no study have been conducted on Achhami bull semen till date. Therefore, the objective of the present study was designed to evaluate the seminal attributes, post-thawed sperm quality and cryo-banking of indigenous Achhami bull semen.

\section{MATERIALS AND METHODS}

The study was conducted between November 2014 to February 2015 at the Animal Breeding Division, Nepal Agricultural Research Council (NARC), Khumaltar, Lalitpur, Nepal. The division is located at N 27.66 latitude and E 85.35 longitude and $1400 \mathrm{~m}$ above sea level.

\section{Animal and management}

Two sexually matured, apparently healthy Achhami bulls were selected, brought and managed under ex-situ conservation (Fig. 1A). The bulls were aged 3.5 years and 4 years, weighing $165 \mathrm{~kg}$ and $180 \mathrm{~kg}$, body condition score 4 and 4.5 and scrotal circumference $30.4 \mathrm{~cm}$ and $32.6 \mathrm{~cm}$, respectively. They were managed under semi-intensive system. They were provided $8.0 \mathrm{~kg}$ green grass, $1.0 \mathrm{~kg}$ straw and 1.5 to $2 \mathrm{~kg}$ commercial concentrated feed per head per day with the provision of drinking water all the time. They were vaccinated against foot and mouth disease (FMD) and dewormed with Ivermectin twice yearly.

\section{Semen collection and evaluation}

After 6 months of acclimatization, bulls were started training for semen collection. Semen collection and evaluation was performed as described by Jha et al. (2013). Semen was collected twice a week using artificial vagina (AV) following two successive false mount (Fig. 1B). Soon after collection, the semen volume was recorded and colour was scored visually into 4 grades. The tube containing semen was maintained in water bath at $35^{\circ} \mathrm{C}$. The mass activity was estimated by observing a drop $(5 \mu \mathrm{L})$ of semen without using cover slip and scored into 4 grades under microscope $(40 \times)$. The sperm motility was estimated by observing a drop $(5 \mu \mathrm{L})$ of semen using cover slip under microscope $(100 \times)$. The sperm concentration $\left(\times 10^{6}\right.$ cells/ $\mathrm{mL}$ ) was calculated using haemocytometer technique following the dilution rate at 1:100 (semen: buffered formol saline, Fig. 1C). Acrosome, mid-piece and tail of spermatozoa was examined by wet mount technique using buffered formol saline technique. Ten- $\mu \mathrm{L}$ of diluted formol saline fixed semen was placed on a microscopic slide and observed under microscope $(1,000 \times)$. Sperm head morphology was examined by William's staining technique. A thin and dried stained semen smear with carbol fuschsin
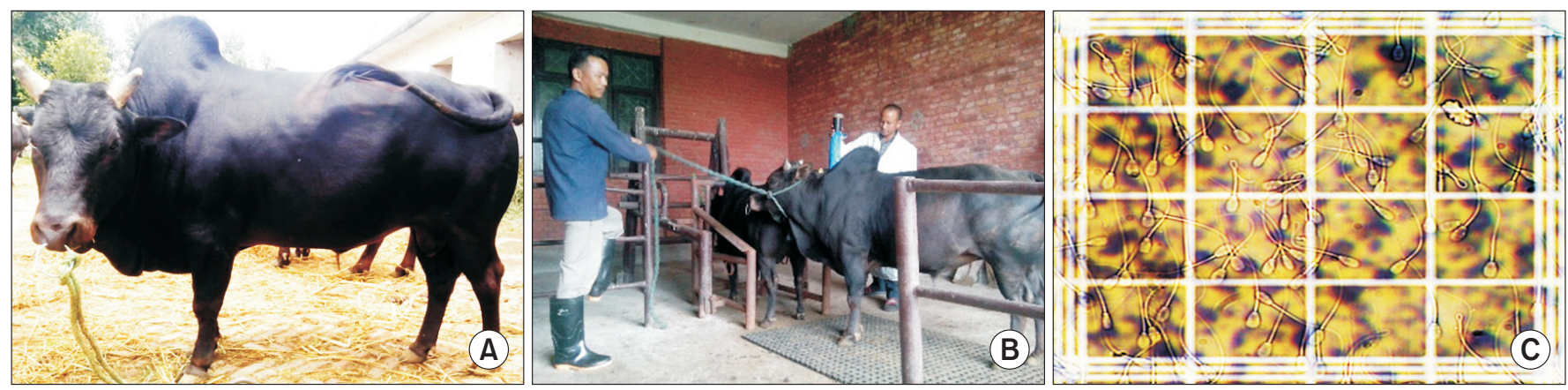

Fig. 1. Photograph of Achhami bull and semen collection. (A) Achhami bull. (B) Semen collection using AV. (C) Sperm concentration by haemocytometer $(400 \times)$. 
was examined under microscope $(1,000 \times)$. Sperm viability was estimated by using eosin-nigrosin staining technique, and observing under microscope at $400 \times$. At least 200 spermatozoa were examined from each smear. Photographs were captured by digital eyepiece camera (Coslab TM, MDCE-5C, China) and Differential Interference Contrast (DIC) optics (Olympus ${ }^{\circledR}, \mathrm{Bx} 51$ Olympus Optical Co. Ltd., Tokyo, Japan) equipped with the microscope.

\section{Semen dilution and cooling}

Semen dilution and cooling was performed as described by Jha et al. (2013). Altogether 4 ejaculates (having $\geq 2 \mathrm{~mL}$ semen volume, $\geq 75 \%$ of sperm motility and $\geq 1,000 \times$ $10^{6}$ cells $/ \mathrm{mL}$ of sperm concentration) from each bull were considered for dilution and freezing. Egg-yolk-tris-citrate extender was used for semen dilution. Semen extender was prepared into two fraction (Part A and Part B) using the following ingredients: $1.221 \mathrm{~g}$ Tris, $0.68 \mathrm{~g}$ citric acid monohydrate, $0.5 \mathrm{~g}$ monohydrate glucose, $7 \mathrm{~mL}$ glycerol (only in extender Part B), $40 \mathrm{~mL}$ double distilled water (Part A) and $33 \mathrm{~mL}$ double distilled water (Part B). After proper mixing, $10 \mathrm{~mL}$ fresh hens yolk, 50,000 IU Penicillin G and $0.05 \mathrm{~g}$ Streptomycin sulphate were added separately to each part; mixed thoroughly and maintained at $35^{\circ} \mathrm{C}$. Semen was diluted following two step dilution protocol to obtain a final sperm concentration of $25 \times 10^{6}$ cells/ $0.25 \mathrm{~mL}$ French mini straw. The calculated volume of extender Part A (without glycerol) was mixed with semen at $35^{\circ} \mathrm{C}$. The diluted semen (semen + extender Part A) and calculated volume of extender part B (with glycerol) were transferred to cold handling cabinet at $5^{\circ} \mathrm{C}$. After $90 \mathrm{~min}$ of cooling at $5^{\circ} \mathrm{C}$, the extender Part B (with glycerol) was mixed with diluted semen (semen + extender Part A) and left at $5^{\circ} \mathrm{C}$ for $210 \mathrm{~min}$ for glycerol equilibration. The final diluted semen suspension was loaded into straws, sealed with poly vinyl chloride (PVC) powder.

\section{Freezing and thawing of spermatozoa}

Freezing of semen straw was done by exposing in liquid nitrogen $\left(\mathrm{LN}_{2}\right)$ vapour in a styrofoam box as described by Jha et al. (2013). Following glycerol equilibration, the semen straws were arranged horizontally onto semen straw rack and was placed at $4.5 \mathrm{~cm}$ above the level of $\mathrm{LN}_{2}$ within the Styrofoam box with its lid closed for $12 \mathrm{~min}$. The semen straw were plunged into liquid nitrogen, transferred into goblet and stored in cryocan. Semen thawing was carried out in a water bath at $37^{\circ} \mathrm{C}$ for $20 \mathrm{sec}$. For microscopic evaluation, two semen straws per batch were thawed to examine sperm motility and viability under microscope. For more conformation, randomly altogether 4 frozen semen straw was sent to National Livestock Breeding Centre, Pokhara, Nepal for the post-thawed sperm evaluation under computer-assisted sperm analysis (CASA, AndroVision $^{\circledR}$, Minitube, Germany) system.

Table 1. Seminal attributes of fresh Achhami bull's semen

\begin{tabular}{ccccccccc}
\hline $\begin{array}{c}\text { Bull } \\
\text { ID }\end{array}$ & $\begin{array}{c}\text { Volume } \\
(\mathrm{mL})\end{array}$ & Colour & $\begin{array}{c}\text { Mass } \\
\text { activity }\end{array}$ & $\begin{array}{c}\text { Motility } \\
(\%)\end{array}$ & $\begin{array}{c}\text { Viability } \\
(\%)\end{array}$ & $\begin{array}{c}\text { Concentration } \\
\left(\times 10^{6} \text { cells/mL) }\right.\end{array}$ & $\begin{array}{c}\text { Abnormal acrosome, } \\
\text { mid-piece \& tail (\%) }\end{array}$ & $\begin{array}{c}\text { Abnormal } \\
\text { head }(\%)\end{array}$ \\
\hline A-101 & $4.4 \pm 0.5$ & $2.5 \pm 0.1$ & $3.5 \pm 0.1$ & $77.0 \pm 1.1$ & $94.4 \pm 0.5$ & $1137.7 \pm 73.7$ & $10.2 \pm 0.5$ \\
A-102 & $2.5 \pm 0.2$ & $2.4 \pm 0.1$ & $3.5 \pm 0.1$ & $78.3 \pm 1.3$ & $91.0 \pm 0.6$ & $1060.0 \pm 44.3$ & $10.3 \pm 0.5$ & $8.2 \pm 0.3$ \\
\hline
\end{tabular}

Colour (1-4 grades): 1=Watery; 2=Yellowish white; 3=Milky white; 4=Creamy white.

Sperm mass activity (1-4 grades): 1=No mass activity; 2=Slow wave motion without forming any waves; $3=$ Rapid wave motion with formation of eddies at the end of waves; $4=V e r y$ rapid wave motion with distinct with distinct eddies.

Table 2. Seminal Attributes of fresh Achhami bull's semen

\begin{tabular}{|c|c|c|c|c|c|c|c|c|c|c|c|c|c|c|c|c|}
\hline \multirow[t]{2}{*}{$\begin{array}{l}\text { Bull } \\
\text { ID }\end{array}$} & \multicolumn{2}{|c|}{$\begin{array}{l}\text { Volume } \\
\text { (mL) }\end{array}$} & \multicolumn{2}{|c|}{ Colour } & \multicolumn{2}{|c|}{ Mass activity } & \multicolumn{2}{|c|}{ Motility (\%) } & \multicolumn{2}{|c|}{ Viability (\%) } & \multicolumn{2}{|c|}{$\begin{array}{l}\text { Concentration } \\
\left(\times 10^{6} \text { cells } / \mathrm{mL}\right)\end{array}$} & \multicolumn{2}{|c|}{$\begin{array}{c}\text { Abnormal } \\
\text { acrosome, } \\
\text { mid-piece \& tail (\%) }\end{array}$} & \multicolumn{2}{|c|}{$\begin{array}{c}\text { Abnormal } \\
\text { head (\%) }\end{array}$} \\
\hline & Min. & Max. & Min. & Max. & Min. & Max. & Min. & Max. & Min. & Max. & Min. & Max. & Min. & Max. & Min. & Max. \\
\hline$A-101$ & 0.8 & 12.3 & 1.0 & 3.0 & 3.0 & 4.0 & 70 & 90 & 87 & 98 & 325 & 2,100 & 6 & 17 & 3 & 11 \\
\hline$A-102$ & 1.0 & 6.0 & 1.0 & 3.0 & 2.0 & 4.0 & 60 & 90 & 87 & 97 & 800 & 1,865 & 6 & 17 & 4 & 11 \\
\hline
\end{tabular}



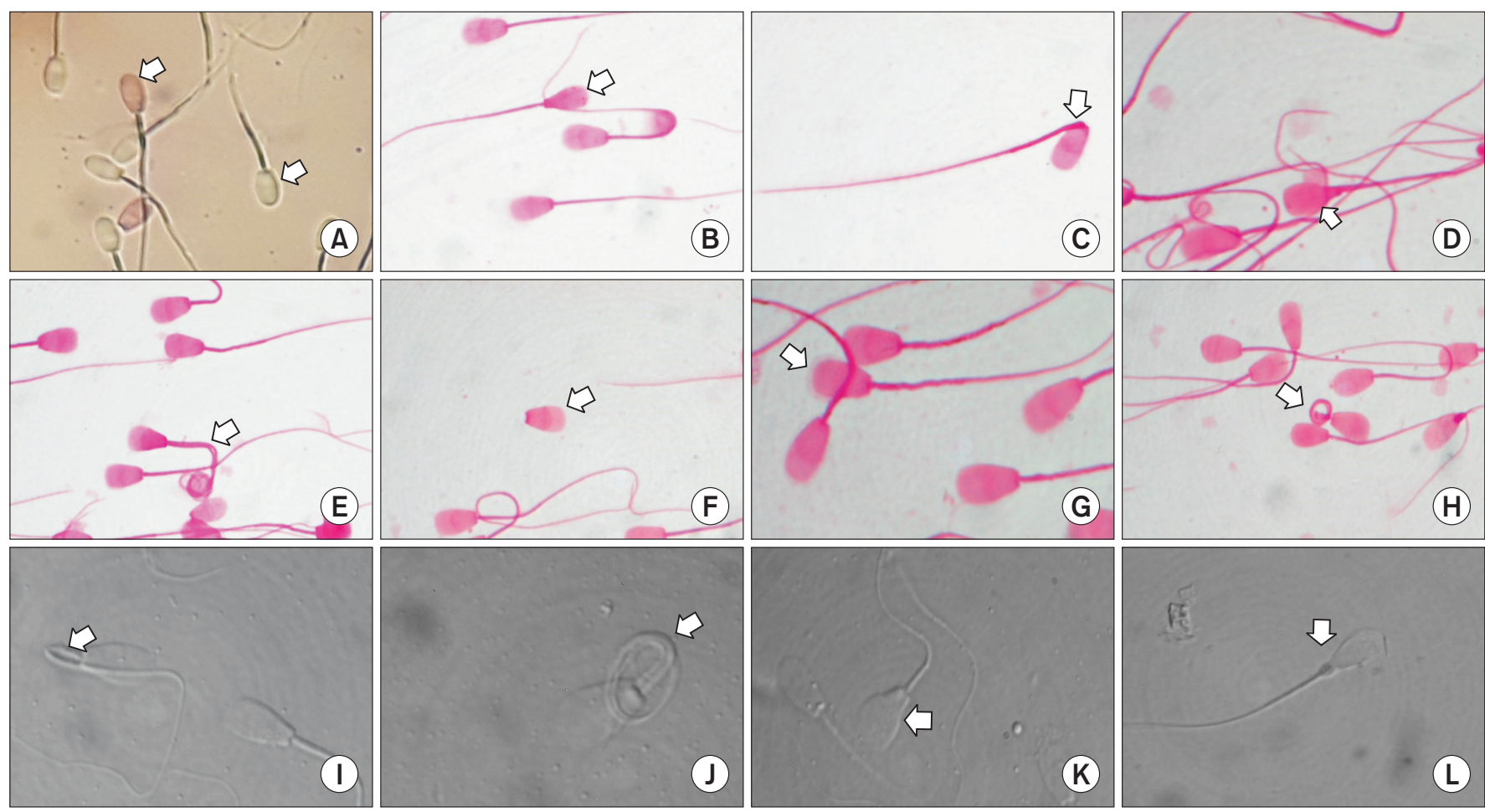

(1)
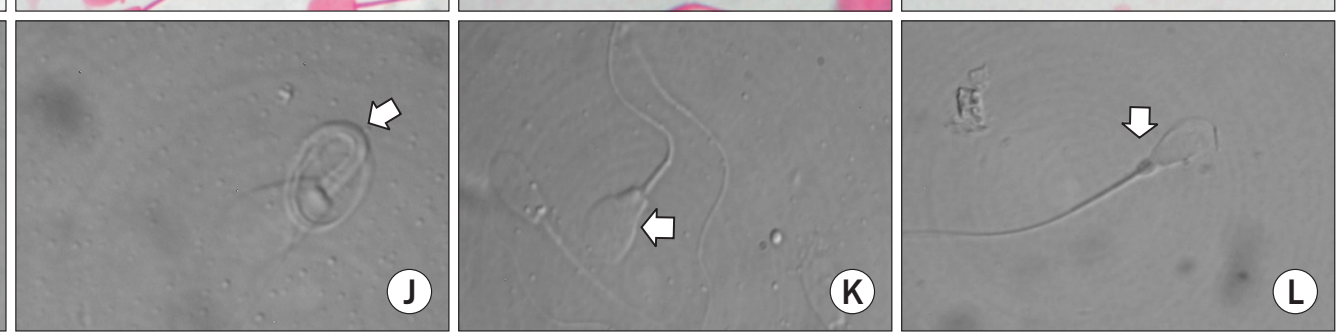

Fig. 2. Photomicrographs of sperm cells during semen evaluation. (A) Eosine-nigrosine (dead and live). (B) Pear shaped head. (C) Brocken neck. (D) Giant head. (E) Double mid-piece and flat head. (F) Brocken head. (G) Loose acrosome. (H) Double coiled tail. (I) Simple bent tail. (J) Double coiled tail. (K) Giant head. (L) Proximal cytoplasmic droplet.

\section{Statistical analysis}

Descriptive analysis (Mean \pm SEM) of seminal parameters (semen volume, colour, sperm mass activity, motility, viability, concentration and abnormal sperm morphology) of fresh semen of each bull was compared with the help of MS Excel in computer. Similarly, the post-thawed sperm motility and viability of each bull was compared.

\section{RESULTS}

\section{Seminal attributes of fresh semen}

A total of 16 ejaculates; 8 ejaculates from each Acchami bull were evaluated for semen volume, colour, sperm mass activity, motility, viability, concentration and abnormal sperm morphology (Table 1 and 2). The mean semen volume of two Acchami bulls were $4.4 \pm 0.5 \mathrm{~mL}$ vs. $2.5 \pm 0.2$ $\mathrm{mL}$ and ranged from $0.8 \mathrm{~mL}$ to $12.3 \mathrm{~mL}$. The semen colour varied from water to milky white (scored into 1-3 grades). The mean sperm mass activity was scored as grade 3 and ranged from 2-4 grades. The mean sperm motility was $77.0 \pm 1.1 \%$ vs. $78.3 \pm 1.3 \%$ and ranged from $60-90 \%$. The mean sperm viability was $94.4 \pm 0.5 \%$ vs. $91.0 \pm 0.6 \%$
Table 3. Post-thawed motility and viability of Achhami bull's sperm cells

\begin{tabular}{ccc}
\hline Bull ID & Motility (\%) & Viability (\%) \\
\hline A-101 & $53.0 \pm 2.0$ & $80.2 \pm 0.4$ \\
A-102 & $50.0 \pm 0.0$ & $73.2 \pm 0.7$ \\
\hline
\end{tabular}

and raged from $87-98 \%$. The live and dead spermatozoa are shown in Fig. 2A. The mean sperm concentrations was $1137.7 \pm 73.7 \times 10^{6}$ cells $/ \mathrm{mL}$ vs. $1060.0 \pm 44.3 \times$ $10^{6}$ cells $/ \mathrm{mL}$ and ranged from $325 \times 10^{6}$ cells $/ \mathrm{mL}$ to 2,100 $\times 10^{6}$ cells $/ \mathrm{mL}$. The mean sperm acrosome, mid-piece and tail ab-normalities was $10.2 \pm 0.5 \%$ vs. $10.3 \pm 0.5 \%$ and ranged from $6-17 \%$. Whereas, the mean sperm head abnormalities was $6.7 \pm 0.5 \%$ vs. $8.2 \pm 0.3 \%$ and ranged from 3 to $11 \%$. The sperm abnormalities were recorded Pear shaped head (Fig. 2B), Brocken neck (Fig. 2C), Giant head (Fig. 2D), Double mid-piece and flat head (Fig. 2E), Brocken head (Fig. 2F), Loose acrosome (Fig. 2G), Double coiled tail (Fig. 2H and 2J), Simple bent tail (Fig. 2I), Giant head (Fig. 2K) and Proximal cytoplasmic droplet (Fig. 2L). 
Table 4. Post-thawed motility parameters of Achhami bull's sperm cells by CASA system

\begin{tabular}{lc}
\hline Sperm motility parameters & Percentage of sperm cells \\
\hline Progressive sperm motility & 75.0 \\
Fast motility & 68.0 \\
Slow motility & 7.4 \\
Local motility & 16.6 \\
Immotile & 8.6 \\
\hline
\end{tabular}

\section{Post-thawed semen quality}

The result of post-thawed sperm motility and viability are shown in Table 3. The mean sperm motility and viability of two Achhami bulls were $53.0 \pm 2.0 \%$ vs. $50.0 \pm$ 0.0 and $80.2 \pm 0.4 \%$ vs. $73.2 \pm 0.7 \%$, respectively. While, in computer-assisted sperm analysis (CASA) system, the progressive motility, fast motility, slow motility, local motility and immotile sperm were $75 \%, 68 \%, 7.4 \%, 16.6 \%$ and 8.6\%, respectively (Table 4).

\section{Cryo-banking}

A total of 620 doses semen straw produced from both the bulls were cryo-banked for future use at Gene Bank, Animal Breeding Division, Agricultural Research Council, Nepal (Table 5).

\section{DISCUSSION}

Due to wide climatic variation, only two Achhami bulls were brought and managed under ex-situ conservation and therefore, the seminal attributes of those two bulls were only studied. It is hard to say that the evaluated seminal attributes represents the average Achhami breed seminal attributes. The seminal attributes included in this study were semen volume, colour, sperm mass activity, motility, viability, concentration and abnormal morphology. Evaluation of semen characteristics allows the detection and elimination of male infertility or subfertility (Verstegen et al., 2002; Madhuri et al., 2012). The mean semen volume was comparatively lower than those reported $4.32 \pm 0.24 \mathrm{~mL}$ in Cross bred bulls (Chauhan et al., 1983), $3.40 \pm 1.30 \mathrm{~mL}$ for indigenous non-descript zebu (Siddiqui et al., 2008), $3.10 \pm 0.35 \mathrm{~mL}$ in semi wild Mithun (Bhattacharya et al., 2009), $3.25 \pm 0.15 \mathrm{~mL}$ in Punganur bulls (Bramhaiah, 2012), $9.25 \pm 2.5 \mathrm{~mL}$ in Gir bulls (De Lucio et al., 2014), $4.06 \mathrm{~mL}$ to $4.49 \mathrm{~mL}$ in Red Sindhi bulls (Tiwari et al., 2012) and $11.5 \mathrm{~mL}$ in Friesian and
Table 5. Number of frozen straw preserved in gene bank, animal breeding division

\begin{tabular}{cc}
\hline Breed & No. of straw \\
\hline Achhami & 620 \\
\hline
\end{tabular}

$9.8 \mathrm{~mL}$ Sahiwal (Hossain et al., 2012), respectively. The normal colour of bull semen is milky white or light yellow. The colour of semen mainly vary due to presence of pigment lipochrome or riboflavin (Hafez, 1980; Patel and Siddiquee, 2013). The mass activity recorded in our study is consistent with Fiaz et al. (2010) who reported mass activity of $2.21 \pm 0.04$ to $3.15 \pm 0.12$ (scale: $0-5$ ) in Jersey bull. Similarly, our finding of mass activity is comparable with Singh and Pangawkar (1990) who reported $3.10 \pm$ $0.54,3.00 \pm 0.11,2.88 \pm 0.08,2.83 \pm 0.06$ and $2.80 \pm$ 0.06 (scale: $0-4$; 0 -sperm show no signs of movement, 1-sperm move but fail to progress forward, 2-sperm move slowly and in a poorly defined direction, 3-sperm move forward but a slower speed and/or in a curved direction, and 4-fast and forward progression where sperm move in a straight direction) in different Holstein Friesian (HF) and Jersey cross bulls. The sperm motility found in our study was higher with Chauhan et al. (1983), Farooq et al. (2013) and De Lucio et al. (2014) who reported $64.2 \pm 0.88 \%$ to $59.86 \pm 0.76 \%$ in crossbred bulls, $64.38 \pm 2.64 \%$ in Cholistani bulls, $62.10 \pm 5.8 \%$ in Gir bulls and $65.20 \pm 3.9 \%$ in Nellore bulls. The sperm motility was comparable with Bramhaiah (2012) and Hossain et al. (2012) who reported $72.85 \pm 0.71 \%$ in pure bull breeds and $64.0 \%$ in Friesian and, $68.8 \%$ in Sahiwal bulls, respectively. The sperm viability in our study is within the range $80.6 \pm 10.7$ to $92.4 \pm 6.3 \%$ in pure Jersey bulls (Sugulle et al., 2006). The percentage of live or dead sperm may be attributed due to frequency of collection, age of breeding bull and season. The sperm concentration in our present study was comparable with Farooq et al. (2013) and Tiwari et al. (2012) who reported $1062.22 \pm 101.26 \times 10^{6}$ cells/ $\mathrm{mL}$ in Cholistani and $963.22 \pm 23.96$ to $1133.49 \pm 34.85$ $\times 10^{6}$ cells $/ \mathrm{mL}$ in Red Sindhi bulls, respectively. In contrast, higher sperm concentration was reported 1473.90 $\pm 343.2 \times 10^{6}$ cells $/ \mathrm{mL}$ in Gir and $1662 \pm 343.80 \times 10^{6}$ cells/mL in Nellore bulls (De Lucio et al., 2014), 1355.3 $\times 10^{6}$ cells $/ \mathrm{mL}$ in Friesian and $1858.4 \times 10^{6}$ cells $/ \mathrm{mL}$ in Sahiwal bulls (Hossain et al., 2012), respectively. However, lower sperm concentration was reported $766.69 \pm 5.50$ $\times 10^{6}$ cells $/ \mathrm{mL}$ in Sahiwal bulls (Bhakat et al., 2011) and 
$890.47 \pm 18.45$ to $995.16 \pm 70.99 \times 10^{6}$ cells $/ \mathrm{mL}$ in Jersey bulls (Farooq et al., 2013), respectively. The difference in sperm concentration is due to individual genetic variation. The sperm concentration is affected by age- as increase in sperm concentration with increasing age while decrease in sperm concentration with successive frequent ejaculation by 19-55\% (Kaya et al., 2002). Higher sperm concentration allow to produce higher number of insemination doses ultimately create opportunity to inseminate larger number of females (Robinson et al., 2006). The total abnormal sperm count in our study is within the range reported by Vilakazi and Web (2004), Farooq et al. (2013) and De Lucio et al. (2014) who reported $20.30 \pm 1.3 \%$ in Friesland bulls, $16.03 \%$ in Cholistani bulls and $17.0 \pm$ 9.0\% in Gir bulls. The average quality of semen should not contain more than $20 \%$ abnormal sperm, while semen containing more than $30 \%$ abnormal sperm would be considered as poor (Hafez, 1993). The quality of bull semen might be affected by genetic or non-genetic factors like temperature, photoperiod, humidity and nutrition (Haugan et al., 2005). The differences in seminal parameters might be due to breed, age, body weight, nutritional status and size of the testicles (Almquist et al., 1979). The size of the testicles increases with advancement of age (Toe et al., 2000). The body weight is more important than age in determining testicular growth and development, its influence on semen quality (Notter et al., 1985). Variations also attributed by season of collection, sexual excitement, method and frequency of semen collection (Lagerlof, 1934).

The post-thawed sperm motility in this study was in consistent with Tiwari et al. (2012), Mishra et al. (2012) and Kedia et al. (2014) who reported $50.05 \pm 0.03$ to $50.19 \pm 0.06 \%$ in Red Sindhi bulls and $49.64 \pm 2.06 \%$ to $51.16 \pm 1.08 \%$ in Jersey and Sahiwal bulls, respectively. In contrast, the sperm motility was lower $46.00 \pm 1.16 \%$ in Gir bulls (Rana and Dhami, 2004), 62.3\% in Fresian and 63.6\% in Sahiwal bulls (Hossain et al., 2012). Acceptable post-thawed motility was reported $54.02 \pm 2.71$ to 57.85 \pm 1.61 in different pure bull breeds (Farooq et al., 2013; Patel and Siddiquee, 2013). The post-thawed sperm viability in this study was higher than Nath et al. (1996) who reported $66.50 \pm 2.25 \%$ in pure Jersey bulls. However, Veeraiah et al. (1999) and Salvador et al. (2008) who reported much lower post-thawed viability $44.69 \pm 1.00 \%$ and $34.50 \pm 11.1 \%$ in Nellore and Ongole bulls. However, the post-thawed sperm viability was comparable with $\mathrm{Fa}$ rooq et al. (2013) who reported much higher post-thawed viability $71.89 \pm 2.05 \%$ in Cholistani bulls. The result of post-thawed semen quality depends upon several factors like type of extender used for processing semen, the amount of glycerol included in the extender, the rate of cooling used, equilibration period, packaging and rate of freezing and thawing of the semen (Gaillard and Kupferschmied, 1982). The motility and viability of sperm vigorously decreased due to cold shock and cryo injuries during cooling and freezing of sperm cells. Cold shock usually takes place when the semen temperature rapidly decreases from approximately body temperature of the bull $\left(35^{\circ} \mathrm{C}\right)$, to the freezing temperature of water $\left(0^{\circ} \mathrm{C}\right)$ (Bailey et al., 2000; Medeiros et al., 2002). The quality of semen deteriorates as the spermatozoa undergoes several ultrastructural, biochemical and functional changes during freezing and thawing (Salamon and Maxwell, 2000). The variation may occur due to different type of extender including the concentration of glycerol and egg yolk used for processing semen (Gaillard and Kupferschmied, 1982). The reduction of live and motile sperm percentage could be attributed to the death of the spermatozoa due to cold shock which is attributed as a result in rate of cooling and glycerol equilibration time during processing of semen for freezing semen (Bailey et al., 2000).

\section{CONCLUSION}

The semen volume was comparatively lower however, the sperm concentration, motility, viability and abnormal percentage were comparable with most of the bull's breeds. Due to the acceptable post-thawed sperm motility and viability recorded, cryopreservation of Achhami bull semen is hereby recommended so as to preserve the Achhami breed. For further validation, the fertility will be observed from the produced frozen semen.

\section{CONFLICTS OF INTEREST}

No potential conflict of interest relevant to this article was reported.

\section{ACKNOWLEDGEMENTS}

The authors wish to acknowledge the Nepal Agricultural 
Research Council (NARC) for financial, laboratory facilities and providing the Achhami bulls. Sincere thanks are extended to National Livestock Breeding Office, Pokhara, Nepal for his generosity in examining post-thawed sperm motility using computer-assisted sperm analysis (CASA) system.

\section{AUTHOR'S AFFILIATION, POSITION AND ORCID NO.}

PK Jha, Nepal Agricultural Research Council, Scientist, https://orcid.org/0000-0001-6374-9201

S Sapkota, Nepal Agricultural Research Council,

Scientist, https://orcid.org/0000-0002-2930-2219

NA Gorkhali, Nepal Agricultural Research Council,

Senior Scientist, https://orcid.org/0000-0003-3592-4652

BR Pokharel, Nepal Agricultural Research Council, Senior

Technician, https://orcid.org/0000-0003-2384-7338

AK Jha, West Bengal Univ., PhD Student,

https://orcid.org/0000-0002-7411-484X

$S$ Bhandari, Nepal Agricultural Research Council, Senior

Technician, https://orcid.org/0000-0003-4398-1278

BS Shrestha, Heifer International, Senior Program Manager,

https://orcid.org/0000-0002-2533-6809

\section{REFERENCES}

Almquist JO, Rosenberger JL and Branas RJ. 1979. Effect of thawing time in warm water on fertility of bovine spermatozoa in plastic straws. J. Dairy Sci. 62:772-775.

Bailey JL, Bilodeau J and Cormier N. 2000. Semen cryopreservation in domestic animals: A damaging and capacitating phenomenon. J. Androl. 21:1-7.

Bhakat M, Mohanty TK, Raina VS, Gupta AK, Khan HM, Mahapatra RK and Sarkar M. 2011. Effect of age and season on semen quality parameters in Sahiwal bulls. Trop. Anim. Health Pro. 43:1161-1168.

Bhattacharyya HK, Goswami BK, Bujarbaruah KM, Deka BC and Biwas RK. 2009. Collection and characterization of semen in Mithun (Bos frontalis) bulls. Theriogenology 72:699703.

Bramhaiah KV, Rao VH, Rao AS, Naidu KV and Viroji Rao ST. 2013. Semen characteristics of Punganur bulls. Indian J. Anim. Res. 47:45-48.

Chauhan FS, Matharoo JS, Takkar OP and Singh M. 1983. Semen characteristics, deep freezing of semen and reproductive performance of crossbred cattle. Indian J. Dairy Sci. 36:96-100.

De Lucio AC, Ferraudo AS, Oliveria de LZ, Carno de AS, Pereira W, Carneio LC, Lima de VFMH, Almedia S, Deragon LA,
Alves BG and Alves KA. 2014. Exploratory analysis of difference in sperm morphology in Nelore and Gir (Bos indicus) bulls. Trop. Anim. Health Pro. 46:765-770.

Dhurvey M, Gupta VK, Nema SP, Patidar A, Shivhare M, Singh $\mathrm{N}$ and Shakya V. 2012. Modern semen evaluation techniques in domestic animals: a review. DHR-IJBLS. 3:62-83.

Farooq U, Ija A, Ahmad N, Rehman H and Zaneb H. 2013. Investigation of semen quality and freezability of cholistani breeding bull- A preliminary study from Cholistani desert of Pakistan. J. Anim. Plant Sci. 23:359-363.

Fiaz M, Usmani RH, Abdullah M and Ahmad T. 2010. Evaluation of semen quality of Holstein Friesian and Jersey bulls maintained under subtropical environment. Pak. Vet. J. 30:75-78.

Gaillard C and Kupferschmied H. 1982. Thawing time and nonreturn rate of bovine semen frozen in fine French straws. Theriogenology 18:487-495.

Hafez ESE. 1980. Artificial Insemination. Reproduction in farm animal. 4th ed, Lea and Febriger, Philadelphia, pp. 521-45.

Hafez ESE. 1993. Reproduction in farm animals. 6th ed, Lea and Febiger, Philadelphia, pp. 405-439.

Haugan T, Reksen O, Gröhn YT, Kommisrud E, Ropstad E and Sehested E. 2005. Seasonal effects of semen collection and artificial insemination on dairy cow conception. Anim. Reprod. Sci. 90:57-71.

Hossain ME, Khatun MM, Islam MM and Miazi OF. 2012. Semen characteristics of breeding bulls at the Central Cattle Breeding and Dairy Farm of Bangladesh. Bang. J. Anim. Sci. 41:1-5.

Jha PK, Paul AK, Rahman MB, Tanjim M, Bari FY and Alam MGS. 2013. Improvement of preservation quality of chilled bull semen using $\alpha$-tocopherol as an antioxidant. J. Emb. Trans. 28:31-39.

Kaya A, Aksoy M and Tekeli T. 2002. Influence of ejaculation frequency on sperm characteristics, ionic composition and enzymatic activity of seminal plasma in rams. Small Rumin. Res. 44:153-158.

Kedia NK, Tiwari RP, Mishra GK, Poyam MR, Pandey AK, Nair AK and Sahasrabhude SA. 2014. Characteristics and Freezability of Tharparkar bull semen. Indian J. Anim. Sci. 84:382388.

Lagerlof N. 1934. Morphological studies on the change in the sperm structure and in the testis of bulla with decreased or abolished fertility. APMIS. 19:254.

Madhuri D, Gupta V, Nema S, Patidar A, Shivhare M, Singh N and Shakya V. 2012. Modern semen evaluation techniques in domestic animals: A review. DHR Int. J. Biomed. Life Sci. 3:62-83.

Medeiros CM, Forell F, Oliveira AT and Rodrigues JL. 2002. Current status of sperm cryopreserva-tion: why isn't it better? Theriogenology 57:327-344.

Mishra SR, Kundu AK and Mahapatra APK. 2013. Effect of ambient temperature on membrane integrity of spermatozoa in different breeds of bulls. The Bioscan 8:181-183.

Nath KC, Ahmed K, Dutta G, Barthakur T and Borgohain BN. 
1996. Semen quality and release of certain enzymes during the course of freezing bull spermatozoa. Indian J. Anim. Reprod. 17:130-131.

Neopane PN and Pokharel PK. 2005. Indigenous cattle of Nepal. Animal Breeding Division, National Animal Science Research Institute (NASRI), Nepal Agricultural Research Council, Khumaltar, Lalitpur, Kathmandu, Nepal, p. 2-8.

Notter DR, Lucas JR, McClaugherty FS and Copenhaver JS. 1985. Breed group differences in testicular growth patterns in spring-born lambs. J. Anim. Sci. 60:622-631.

Patel BR and Siddiquee GM. 2013. Physical and morphological characteristics of Kankrej bull semen. Vet. World 6:405-408.

Rana CM and Dhami AJ. 2004. Physical attributes, intact acrosome, HOS test and freezability of semen of Gir and Jafarabadi bulls. Indian Vet. J. 81:401-410.

Robinson JJ, Ashworth CJ, Rooke JA, Mitchell LM and Mc Evoy TG. 2006. Nutrition and fertility in ruminant livestock. Anim. F. Sci. Tech. 126:259-276.

Salamon S and Maxwell WM. 2000. Storage of ram semen. Anim. Reprod. Sci. 62:77-111.

Salvador DF, Andrade VJ, Vale Filho VR, Dias JC and Nogueira LAG. 2008. Relationship between andrologic profile and semen freezing in two year old Nellore bulls, pre select by breeding soundness evaluation. Arq. Bras. Med. Vet. Zootec. 60:587-593.

Shrestha SL and Shrestha NP. 1998. Indigenous cattle genetic resources. Proceedings of the first national workshop on animal genetic resources conservation and genetic improvement of domestic animals in Nepal. Nepal Agricultural Research Council, Khumaltar, Lalitpur, Nepal, pp. 16-19.

Siddiqui MAR, Bhattacharjee J, Das ZC, Islam MM, Islam MA, Haque MA, Parrish JJ and Shamsudin M. 2008. Cross bred bull selection for bigger scrotum and shorter age at puberty with potentials for better quality semen. Reprod. Domest. Anim. 43:74-79.

Singh DM and Pangawkar GR. 1990. Studies on semen characteristics of exotic and crossbred bulls spermatozoa. Indian J. Anim. Reprod. 11:92-95.

Sugulle AH, Bhuiyan MMU and Shamsuddin M. 2006. Breeding soundness of bull and the quality of their frozen semen used in cattle artificial insemination in Bangladesh. Livest. Res. Rural Dev. 18:54.

Tiwari R, Mishra GK, Singh RB, Rehman SU, Rathora KS, Saxena SK and Siddiqui MU. 2012. Seasonal variations in the quality and freezability of Red Sindhi bull semen. Indian J. Anim. Sci. 82:1344-1346.

Toe F, Rege JEO, Mukasa-Mugerwa E, Tembely S, Anindo D, Baker RL and Lahlou-Kassi A. 2000. Reproductive characteristics of Ethiopian highland sheep I.: genetic parameters of testicular measurements in ram lambs and relationship with age at puberty in ewe lambs. Small Rumin. Res. 36:227-240.

Veeraiah G, Venugopal K and Rao KB. 1999. Effect of various level of glycerol and egg yolk in freezing of Ongole bull semen. Indian J. Anim. Reprod. 20:149-152.

Verstegen J, Iguer-Ouada M and Onclin K, 2002. Computer assisted semen analyzers in andrology re-search and veterinary practice. Theriogenology 57:149-179.

Vilakazi DM and Webb EC. 2004. Effect of age and season on sperm morphology of Friesland bulls at an artificial insemination centre in South Africa. S. Afr. J. Anim Sci. 34:62-69.

Wagle S. 2019. Institutional Strengthening and Awareness Raising for Sustainable Conservation of Critically Endangered Achhami Cattle, Nepal. The Ruffor Foundation. 